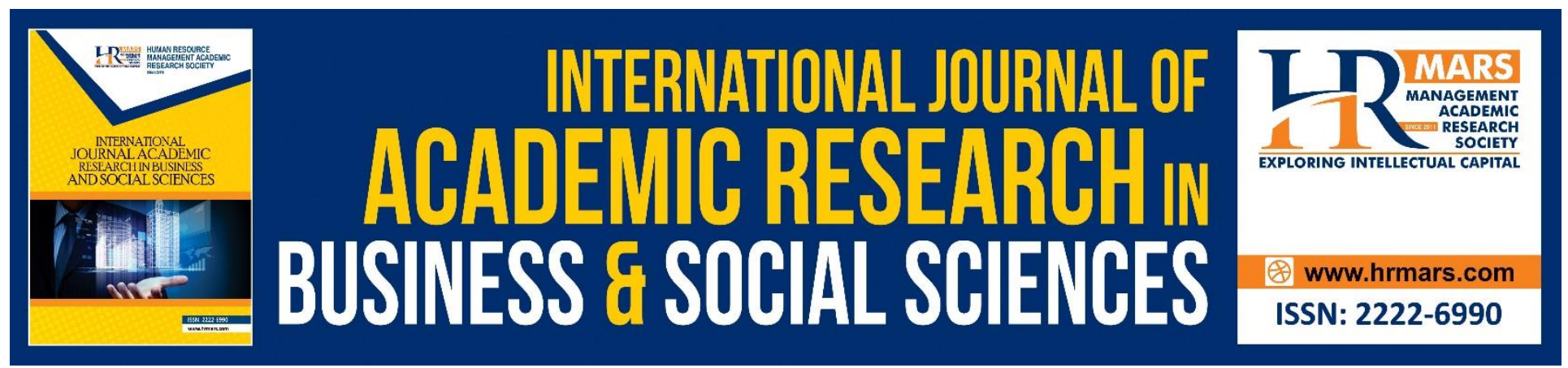

\title{
Online Distance Learning Readiness During Covid-19 Outbreak Among Undergraduate Students
}

Siti Nurshahidah Sah Allam, Mohd Sufiean Hassan, Rosilawati Sultan Mohideen, Aini Faezah Ramlan, Rusydi Mohd Kamal

To Link this Article: http://dx.doi.org/10.6007/IJARBSS/v10-i5/7236

DOI:10.6007/IJARBSS/v10-i5/7236

Received: 20 March 2020, Revised: 21 April 2020, Accepted: 02 May 2020

Published Online: 28 May 2020

In-Text Citation: (Allam et al., 2020)

To Cite this Article: Allam, S. N. S., Hassan, M. S., Mohideen, R. S., Ramlan, A. F., \& Kamal, R. M. (2020). Online Distance Learning Readiness During Covid-19 Outbreak Among Undergraduate Students. International Journal of Academic Research in Business and Social Sciences, 10(5), 642-657.

\section{Copyright: (C) 2020 The Author(s)}

Published by Human Resource Management Academic Research Society (www.hrmars.com)

This article is published under the Creative Commons Attribution (CC BY 4.0) license. Anyone may reproduce, distribute, translate and create derivative works of this article (for both commercial and non-commercial purposes), subject to full attribution to the original publication and authors. The full terms of this license may be seen

at: http://creativecommons.org/licences/by/4.0/legalcode

\section{Vol. 10, No. 5, 2020, Pg. 642 - 657}

http://hrmars.com/index.php/pages/detail/IJARBSS

JOURNAL HOMEPAGE

Full Terms \& Conditions of access and use can be found at http://hrmars.com/index.php/pages/detail/publication-ethics 


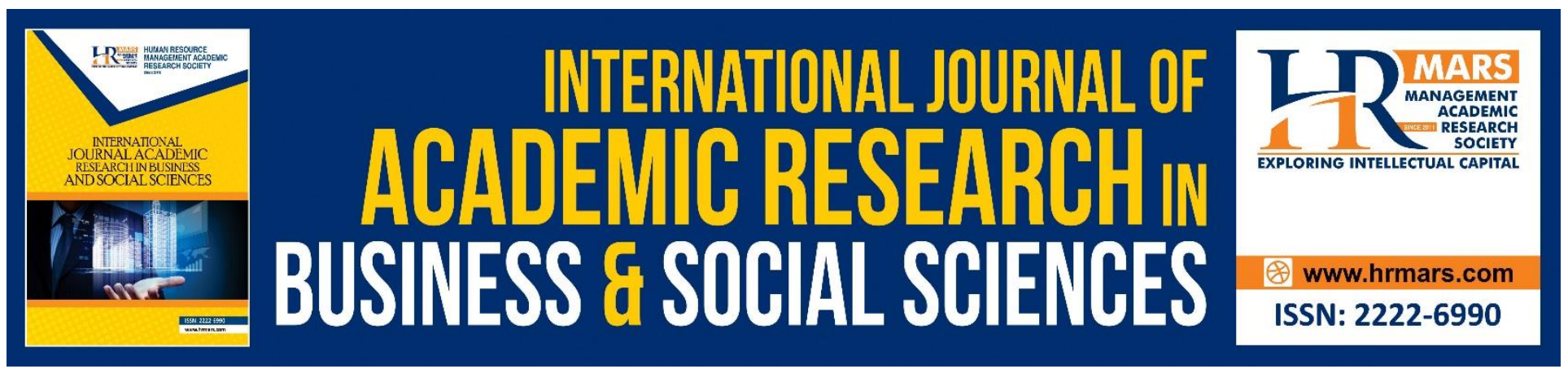

\title{
Online Distance Learning Readiness During Covid-19 Outbreak Among Undergraduate Students
}

\author{
Siti Nurshahidah Sah Allam \\ Universiti Teknologi MARA (UiTM), Melaka Branch, Malaysia \\ Mohd Sufiean Hassan \\ Kolej Universiti Islam Melaka (KUIM), Malaysia
}

Rosilawati Sultan Mohideen, Aini Faezah Ramlan, Rusydi Mohd
Kamal

Universiti Teknologi MARA (UiTM), Melaka Branch, Malaysia

\begin{abstract}
In Malaysia, the COVID-19 outbreak reported day-by-day positive carrier statistic increasing that force government action to impose movement control order (MCO); Malaysian stay at home to stop the virus from spreading fast. The MCO affects the Faculty of Communication and Media Studies undergraduate students who are just starting a new semester in the week fourth to stay at home while learning activities continue using Online Distance Learning (ODL) mode. The implications of online learning are the concern of university as a teaching method that is expected to improve students' academic performance by enhancing computer/Internet literacy competency (CIL), selfdirected learning (SDL), and motivation for learning (MOL) level. Does during the COVID-19 outbreak that spark anxiety and panic are suits for ODL activities? A survey conducted $(n=631)$ among undergraduate students to measure the level of ODL readiness. By using descriptive statistical analysis, this study found that CIL among undergraduate students is at a high level, while SDL and MOL reported at a low level. This study suggests the ARP initiative taken by the lecturer. The ARP refers to attention, recognition, and pressure less. The ODL seems new norms that should not hinder potential interactive learning for best academic performance and to drive excellent achievement. This study highly contributes a new idea to the lecturer, faculty management, the university and $\mathrm{HEI}$ as the best practice of ODL in the future.
\end{abstract}

Keywords: Online Distance Learning, Academic Performance, Computer/Internet Literacy Competency (CIL), Self-directed Learning (SDL) and Motivation for Learning (MOL). 
INTERNATIONAL JOURNAL OF ACADEMIC RESEARCH IN BUSINESS AND SOCIAL SCIENCES Vol. 10, No. 5, May, 2020, E-ISSN: 2222-6990 @ 2020 HRMARS

\section{Introduction}

Coronavirus disease (COVID-19) is an infectious disease triggered by a new virus outbreak from Wuhan, China. The COVID-19 has been spreading rapidly across the global, overreaching health services and intensified with the shelter confinement. Global disease outbreak such as Middle East respiratory syndrome coronavirus (MERS-CoV) from Saudi Arabia, Influenza A (H1N1) from Spain, Henipavirus (Nipah) from China and Severe acute respiratory syndrome (SARS) increase death rate statistic, basically, affect Malaysia sphere but not forcing government action to quarantine movement.

COVID-19 outbreak in Malaysia early 2020 reported day-by-day positive carrier statistic increasing that force government action to impose movement control order (MCO); Malaysian stay at home to stop the virus from spreading fast. The MCO affects Communication and Media Studies undergraduate students who are just starting a new semester in the week fourth to stay at home but learning activities continue using Online Distance Learning (ODL) method.

Little and not exaggerate to mention, no study conducted on ODL due to disease outbreak that creates spark panic and fear; force current semester students complete their study and new teaching method that rarely apply during 'peace situation'. Most of ODL study directed due to the fact that the nature of the study programme or syllabus mode in ODL; structured, well-planned class activity and monitored for quality academic purposes. Besides, many researchers found that ODL brought advantages in teaching and learning activities compared to conventional; face-to-face method. However, the future researcher needs to consider ODL method chosen by the university due to disease outbreak and findings surprisingly and urged standard operation (SOP) for ODL conducted.

Faculty of Communication and Media Studies (FKPM), University Teknologi MARA, Melaka, Malaysia have three undergraduate academic programs and most of the syllabus went through blended learning (online learning) but not mandatory just optional. By using i-learn (online learning platform initiate by the university), Google Classroom, Skype and Facebook Live majority of students enjoy the learning activities conducted by lecturer due to the fact that students can study from anywhere, flexibility to choose learning session, saving time and money (mobility from residential college to a classroom) but they still have social interaction with the lecturer for assessment and lecture consultation. Totally different mode for ODL where the student started their learning activities from home with no physical social interaction with lecturer and groupmate to perform course assessment and expected destruction occur can affect academic performance. These are the challenges expected occur in applying distance education during a disease outbreak.

The conceptual definition of distance education stated that the teaching method in which students completed their study from anywhere but not always be physically come to the lecture session. In other words, a student learns, study, and completed in their registered courses through online learning without having to attend any physical class such as lecture hall, computer lab, library or any physical classes. According to (Kenny, 2010), the most of distance education today fully utilize the Internet network and easy access for the vast majority of students either through laptop or mobile phone (Hussin et al., 2017) whether in their own homes.

The term online distance learning is also used interchangeably with terms like e-learning (Keis et al., 2017), blended learning (Deschacht \& Goeman, 2015), online learning (Wallace, 2010) and virtual learning with the main idea stated that learning activities in an informal form, utilize any Internet tools and little or no physical social interaction with lecturer (Kuo et al., 2014). Besides, these teaching methodology approaches are used to deliver course content through teleconferencing (Bhat 
et al., 2018), online chatting or forum , interactive video, recorded video and audio. By using online teaching materials delivery, students are expected to have a stable Internet network connection, workable hardware and high online learning readiness level. The most important factors need to consider for ODL methods are the student must possess computer/Internet literacy (Hernándezsellés \& Muñoz-carril, 2019), self-directed learning (Garrison, 1987) and high level motivation of learning (El-Seoud, 2016) to complete their study.

The purpose of this study to measure the level of computer/internet literacy, self-directed learning and motivation of learning among undergraduate students in order to provide view student online learning readiness to the faculty management and the lecturers for teaching planning.

\section{Literature Review}

Online Distance learning (ODL) known as online distance education (D Randy Garrison, 1987), elearning (Keis et al., 2017), blended learning (Deschacht \& Goeman, 2015), interactive learning and virtual learning is a form of education in which the key practice include physical separation of lecturers and students and the use of various online applications innovate to facilitate interactive communication between lecturers and students. Students and institutions embrace distance learning with a good reason.

Universities benefit by adding students without having to construct classrooms and housing, and students reap the advantages of being able to work where and when they choose (Doculan, 2016). Basically, ODL practice flexible learning activities to enhance access to education for the society, flexible learning for disable or unhealthy people and rarely grab researchers attention is to examine the conduct of ODL during pandemic disease where the approach is not same to ODL program enrol by students (Kenny, 2010).

The early year of 2020, Malaysian shocked with the attack of coronavirus known as COVID-19 and seriousness level force to government action to apply for movement control order. This order is based on Prevention and Control of Infectious Diseases Act 1988 and the Police Act 1967 where most of the Malaysian subject to home quarantine for 14 days. Sudden command by government spark fear and panic situation that directly affect the education system. All education centre such as school, college and university ordered to stop the operation immediately. As for the higher learning education system, they are allowed to go back home, all teaching and learning activities hold until next order given by the government.

As a result, fear and panic infected among teachers and lecturers how to complete the syllabus and the most relevant method are ODL. Being and educators, they are facing multiple issues in conducting ODL such as little exposure to set up the platform (zoom meeting, Google Hangout Meet, Telegram, Google Classroom etc), concerning student participation (Foon \& Sum, 2014), limited assessment method to measure course learning outcomes (Zhu et al., 2018) and less experience to develop e-content. Besides, educators are concerned about device and Internet access among students to join ODL sessions, technical issues facing by students to join ODL activities such as do not have email to sign up a new account, can student explore how to use tools in the platform, do they know how to search the assessment uploaded, basically, trigger another panic among educators.

Besides educators, student's anxiety to join the ODL activities must take into consideration. Before planning ODL activities, educators need to analyse about Internet access connection and ability to use computer that develop anxiety (Tuncay, 2010), especially students in a sub-rural and rural area, does student be able to complete the task listed in ODL activities independently without 
physical discussion with friends and lecturers (Ajmal \& Ahmad, 2019), student's motivation to complete study while facing interruption and difficulties at home. Potential factors mentioned suggested significantly affect students online learning readiness level (Hung et al., 2010) and academic performance (Saadé et al., 2017).

Prediction of this study supported by the previous research that highlighted the shortcomings of ODL experience among undergraduate students. Most of the study conducted to examine online learning mode as the nature of the study programme rather than during pandemic disease that sparks panic, anxiety and fear feeling among students. According to Newman (2008), drawbacks of the online learning experience by respondents who generally choose among undergraduate students reported that Internet speed connection caused frustrations.

The ODL activities listed by the lecturer can't be performed by students and it's trigger anxiety that leads fear to achieve the best result for the course enrolled. Besides Internet speed connection, basic computer skills that need student's ability to participate in ODL must have at least a satisfactory level to use a computer, software, applications and online learning tools (Suprabha et al., 2017). The competency of using computer and access to Internet connection skill align with student online learning readiness dimension (Hung et al., 2010).

Furthermore, lack of self-discipline that refers to self-directed learning influence readiness level due to environmental interruption such as working commitment and massive home environment. Besides, friend interruption during ODL session by inviting the student to join online conversation such as chatting, online shopping and gossiping influence readiness level and self-discipline. The student who lacks self-discipline and lower level of motivation can fall in the attrition group of student that affect their academic performance and achievement.

Another grey area of ODL, feeling of isolation with no physical social interaction to their lecturer and classmate that influence level of readiness. Lack of physical social interaction stimuli level of anxiety, low self-confident to perform ODL task and increase procrastination chances. All factors highlighted in this study align with Student Online Learning Readiness (SOLR) Model that consists of social competencies with the instructor, communication competencies, social competencies with classmates, and technical competencies. However, this study chooses common term used by the previous researcher to measure student online learning readiness level that predicted applicable to online distance learning such as computer and internet literacy, self-dependent learning and motivation of learning dimension (Hung et al., 2010).

\section{Computer and Internet Literacy enhance Student Online Distance Learning Readiness}

As ODL becomes useful to learning institutions, especially during a pandemic disease outbreak, an observation of online learning readiness is vital for the successful implementation of ODL as a platform for learning. Success in ODL can be achieved by understanding student online learning readiness environments such as competency of using a computer and to reach Internet access (Thammathirat \& Tuntirojanawong, 2013). An assessment of computer and Internet literacy (known as $\mathrm{CIL}$ in this study) is required for successful implementation of an ODL among students.

In ODL, personal computers/laptops are used as educational supports hardware and computer literacy level is to ensure students able to work independently for completing ODL activities (Suprabha et al., 2017). The CIL level measure includes the use of computers for searching reading materials through Internet browser for ODL activities, students can upload and download documents from the Internet and possess the ability to use application or software for ODL. From this study, the 
researcher suggests that the lecturer needs to gather CIL data before conducting ODL activities so that learning session can be reached and participate by students.

Many researchers who study on student online learning readiness reported that CIL dimension significantly influences readiness level among students (Hung et al., 2010). According to Gordon (2013), many students are ready to adopt online learning technology but it must complement with a high competency CIL. Even though most of the students accept ODL as an innovative learning platform but lack of basic computer skills restricted them to use the e-learning platform effectively (Kuo et al., 2014). Besides, a rigorous study on student online learning attitude reported that higher CIL level was correlated with a higher online learning attitude. Eager to explore computer tools and possess the ability to use Internet applications can reduce the symptom of technology stress among students, especially in joining ODL activities (Yang et al., 2018).

It is a different atmosphere in joining the ODL as nature of the academic program mode compared to 'force' to join online learning due to pandemic outbreak, no good plan, highly urge for self-dependent learning, the student has to develop self-motivation learning for academic achievement and equiped themselves with computer/Internet literacy. Much online learning platform such as Google meet, Zoom meeting and Cisco Webex demand the student computer literacy on engaging camera and microphone device to the computer for successful online conversation. Apart from that, the student must competent to participate in online conversation by clicking invited link, waiting for admin approval to join the meeting, ethically aware in joining online conversation mute the microphone to avoid noise unless students intent to participate, using the chat box to response any requirement asked by administration such as fill up a google form for attendance, survey and the students must know how to get lecture notes or video to conduct selfdirected learning.

\section{Self-Directed Learning enhance Student Online Distance Learning Readiness}

Measuring online learning education, self-directed learning (SDL) is a vital dimension and has been noted for decades. Enormous study reveals that SDL enhances the need for learning responsibilities to be independent learner, enjoyable than face-to-face traditional learning, and embedded with a sense of personal autonomy (D Randy Garrison, 1987). In reviewing the literature on SDL, researchers highlighted that a student who has self-directed learning element are possessed high self-disciplined, self-independent study and high self-confident to complete a task in ODL (Zainuddin, 2019).

The idea expands from the knowledge explore by the most cited researcher in SDL, Garrison (1997) who stated that self-directed consist of self-management, self-monitoring and motivation as interacting dimensions towards the comprehensive model of adult education. However, many studies on student online learning readiness separate motivation dimension as another item to be explored that known as a motivation of learning (Hung et al., 2010). This item will discover in the next section of this research.

The notion of SDL in ODL study, the researcher must consider measuring self-independent learning, self-management and self-monitoring level among undergraduate students (Thammathirat \& Tuntirojanawong, 2013). However, this study expands the SDL dimension by measuring self-goal item. Successful students not only be able to manage the learning activities but must know what and how to reach the learning goal for their performance and achievement.

The idea to expand the SDL dimension by including self-goal as unit analysis; this study concern student ability to set up self-goal for achievement driven by self-performance (Annuar \& 
INTERNATIONAL JOURNAL OF ACADEMIC RESEARCH IN BUSINESS AND SOCIAL SCIENCES Vol. 10, No. 5, May, 2020, E-ISSN: 2222-6990 @ 2020 HRMARS

Shaari, 2014). Most of the students set up a high expectation for their academic achievement but how this goal sync with their commitment and performance, especially in ODL mode during the pandemic outbreak.

Expected from this study on SDL students may have difficulty to present high performance on ODL activities during a pandemic outbreak because the mode of study seems strange to them and to work independently, completing the list of assessments with little or no contact with the lecturer (face-to-face classroom), facing difficulty to manage their stress feeling lead to low academic achievement that affects their final result of the study (Barak et al., 2016).

\section{Motivation of Learning enhance Student Online Distance Learning Readiness}

Motivation has been defined as the 'engine' of learning by Paris \& Turner (1994) and supported by Howe (1998) mentioned the fuel of human learning is motivation. By engaging mental activities with physical that produce learning outcomes demand of time, money and commitment. This manufacturing of learning to take place there needs to be some kind of motivation to make the process work (Casaló et al., 2010).

Joining ODL activities during pandemic outbreak helps to make learning feasible to ensure teaching and learning continue for the knowledge transfer (Park \& Yun, 2017). But what makes students join the ODL activities in the first place? To gain practical understandings into the causes of joining ODL during the pandemic outbreak, this study not only have to examine a type of learning activities but researcher also goes a step further and discover what makes learners 'attend' the ODL session.

According to Howe (1998) in principles of abilities and human learning on the role of motivation he claimed that for the student to attend in the learning session, there wishes to be an incentive or motivation raised. Motives and incentives for people attend to learning session 1) to complete the task for all registered courses (Chen, 2017), 2) the student needs to be strongly motivated for higher academic achievement (Samir A. El-Seoud, 2016), 3) by establishing good study habits the student make themselves into the productive learner.

However, integrating technology in the learning process does not positively significant to enhance student's learning motivation level. Online instruction and e-learning activities resulted demand high Internet connection speed (Cooper, 2006), time consuming, effort and commitment to take place. Besides, ODL during pandemic outbreak urge the lecturers to turn the classroom into an online environment. The question is what specifically is required of the lecturers to develop students learning motivation in ODL mode?

The lecturers need to understand their students' motivations while the students must adapt from conventional courses (face-to-face learning) into online classes to complete them (El-Seoud, 2016), they tend to fail for many reasons. This study believed that the success or failure of ODL is related to student motivation and propose suggestion to the lecturers what to do to stimulate student motivation. To stimulate students, the lecturers should keep in mind that motivation must be natured in students. By explaining to their students how the online environment may be used and encourage interaction and collaboration among their students suggested by previous study to strengthening learning motivation.

Beside, build study groups so that students will no longer be studying in isolation and help students to make friends by meeting fellow students in the online environment claimed to develop learning motivation (Kenny, 2010). Furthermore, online social interaction with their students by 
INTERNATIONAL JOURNAL OF ACADEMIC RESEARCH IN BUSINESS AND SOCIAL SCIENCES

Vol. 10, No. 5, May, 2020, E-ISSN: 2222-6990 ㄷ 2020 HRMARS

monitoring the online presence and construct their learning materials reported to enhance students learning motivation (Doculan, 2016).

\section{Research Methodology}

The respondents of this study were 631 student from Faculty of Communication and media studies (FKPM), Universiti Teknologi MARA, Melaka Branch, Malaysia comprising three program of studies. Student selection was based on random sampling. This study use questionnaires as a means of collecting data. Based on the number of respondents $(n=631)$ with complete data in this study, the sample size is large enough as population of FKPM student is 809. Pilot test was conducted before proceeding to the final data collection to make sure that the reliability and validity of the instrument. Cronbach Alpha's reliability coefficient for all three variables, above 0.70 , shows a good internal consistency (Hair et al., 2010).

Table 1 Respondent Demographic Distribution

\begin{tabular}{|c|c|c|c|}
\hline No & Category & Frequency & Percentage \% \\
\hline \multirow[t]{4}{*}{1.} & Programme & & \\
\hline & a) MC110 & 358 & 56.7 \\
\hline & b) MC111 & 155 & 24.6 \\
\hline & c) MC242 & 118 & 18.7 \\
\hline \multirow[t]{7}{*}{2.} & Semester & & \\
\hline & a) Semester 1 & 13 & 2.1 \\
\hline & b) Semester 2 & 238 & 37.7 \\
\hline & c) Semester 3 & 34 & 5.4 \\
\hline & d) Semester 4 & 286 & 45.3 \\
\hline & e) Semester 5 & 41 & 6.5 \\
\hline & f) Semester 6 & 19 & 3.0 \\
\hline \multirow[t]{3}{*}{3.} & Computer/laptop use: & & \\
\hline & Yes & 571 & 90.5 \\
\hline & No & 60 & 9.5 \\
\hline \multirow[t]{3}{*}{4.} & Smartphone use: & & \\
\hline & Yes & 617 & 97.8 \\
\hline & No & 14 & 2.2 \\
\hline \multirow[t]{3}{*}{5.} & Computer/laptop internet access: & & \\
\hline & Yes & 423 & 67.0 \\
\hline & No & 208 & 22.0 \\
\hline \multirow[t]{3}{*}{6.} & Smartphone use internet access: & & \\
\hline & Yes & 593 & 94.0 \\
\hline & No & 38 & 6.0 \\
\hline \multirow[t]{6}{*}{7.} & Internet Data speed & & \\
\hline & a) GPRS & 5 & .8 \\
\hline & b) EDGE & 28 & 4.4 \\
\hline & c) $3 G$ & 244 & 38.7 \\
\hline & d) $4 G$ & 344 & 54.5 \\
\hline & e) $5 G$ & 10 & 1.6 \\
\hline
\end{tabular}


INTERNATIONAL JOURNAL OF ACADEMIC RESEARCH IN BUSINESS AND SOCIAL SCIENCES

Vol. 10, No. 5, May, 2020, E-ISSN: 2222-6990 @ 2020 HRMARS

The adapted instrument was reviewed by a specialist and subsequently a pilot test was conducted to determine the validity of the question. The purpose of this study is to identify the indicator of the research reliable and valid.

\section{Research Instrument}

The questionnaire consists of two parts used as the instrument of this study. Part A consists of general information on demographic variables such as program, semester, computer use, smartphone use, and internet use. Part B contains an e-learning readiness scale adapted from Alem et al., (2016) and Hung et al. (2010). The scale to measure online learning is a well-established scale that has proven its reliability because it is widely used in past studies. After run pre-test and pilot test, reliability Cronbach's Alpha for all three e-learning readiness scales - the constructs of computer internet literacy, self-dependent learning and motivation of learning are between $0.963-0.965$. This scale contains 16 items and is measured using a 5-level interval scale of $1=$ strongly disagree to $5=$ strongly agree. This measurement scale measures computer internet literacy, Self-dependent learning and Motivation of learning.

Table 2: Validity and Reliability

\begin{tabular}{|c|c|c|}
\hline Code & Items & $\begin{array}{c}\text { Cronbach's } \\
\text { Alpha }\end{array}$ \\
\hline$\overline{\text { CIL1 }}$ & I feel confident using computer & .964 \\
\hline CIL2 & $\begin{array}{l}\text { I feel confident in using the Internet (Google, Yahoo) to find or gather } \\
\text { information for online learning }\end{array}$ & .964 \\
\hline CIL3 & $\begin{array}{l}\text { I feel confident to search, download and upload document by using } \\
\text { Internet. }\end{array}$ & .964 \\
\hline CIL4 & I feel confident to use any applications or software for online learning & .963 \\
\hline SDL1 & I carry out my own study plan. & .963 \\
\hline SDL2 & I seek assistance when facing learning problems. & .963 \\
\hline SDL3 & I manage time well. & .963 \\
\hline SDL4 & I set up my learning goals & .963 \\
\hline SDL5 & I have higher expectations for my learning performance & .963 \\
\hline MOL1 & $\begin{array}{l}\text { I am able to complete my work even when there are destructions in my } \\
\text { home (television, children etc) }\end{array}$ & .964 \\
\hline MOL2 & $\begin{array}{l}\text { I am able to complete my work even when there are online destructions } \\
\text { (friends sending email, online chatting and shopping etc) }\end{array}$ & .964 \\
\hline MOL3 & $\begin{array}{l}\text { Even in the face of technical difficulties I am certain I can learn the material } \\
\text { presented in online learning }\end{array}$ & .963 \\
\hline MOL4 & I have motivation to learn for best academic achievement and performance & .965 \\
\hline PUL1 & Using the online learning improves my performances in my studies & .964 \\
\hline PUL2 & Using online learning will increase productivity & .963 \\
\hline PUL3 & Using online learning enhances my effectiveness in my studies & .963 \\
\hline
\end{tabular}


INTERNATIONAL JOURNAL OF ACADEMIC RESEARCH IN BUSINESS AND SOCIAL SCIENCES

Vol. 10, No. 5, May, 2020, E-ISSN: 2222-6990 @ 2020 HRMARS

\section{Data Analysis}

The respondents of this study were 631 student from Faculty of Mass Communication and media studies (FKPM), Universiti Teknologi MARA, Melaka Branch, Malaysia comprising three program of studies; 1) Diploma in Communication and Media (MC110), 2) Diploma in New Media and Contentpreneurship (MC111) and 3) Bach. of Mass Comm. (Hons) Public Relations (MC242). Student selection was based on random sampling. This study use questionnaires as a means of collecting data. Based on the number of respondents ( $n=631$ ) with complete data in this study, the sample size is large enough as population of FKPM student is 809. Pilot test was conducted before proceeding to the final data collection to make sure that the reliability and validity of the instrument. Cronbach Alpha's reliability coefficient for all four variables, above 0.70 , shows a good internal consistency (Hair et al., 2014).

\section{Findings}

Table 3 shows how the five-point likert scale is divided into mean-level scales. The five-point likert scale ranged from 1 (strongly disagree) to 5 (strongly agree). To calculate the mean difference to obtain the mean divided into three categories namely low, medium and high mean, 5 is subtracted by 1 and divided by 3 . Therefore, the interval for each $\mathrm{min}$ is between 1.33 . The low mean levels are 1.00 to 2.33, the moderate mean levels are between 2.34 and 3.67 while the high mean levels are 3.68 to 5.00 as shown in table 3 below.

Table 3 Mean score range

\begin{tabular}{ll}
\hline Mean Scale & Level \\
\hline 1.00 to 2.33 & Low \\
2.34 to 3.67 & Moderate \\
3.68 to 5.00 & High \\
\hline
\end{tabular}

Table 4 shows that the level of students' computer internet literacy by program. It is found that the mean for each program is slightly different between 2.05 to 2.40 . Only MC242 program is at moderate level. While MC111 and MC110 have a low computer internet literacy. Furthermore, the descriptive analysis also found that the percentage of program respondents who scored high was very small with the highest is MC242 (48.3\%) followed by MC111 (38.7\%) and MC110 (29.1\%). Based on the classification of the mean score range, table 4 showed that the overall mean value of the level of Computer Internet Literacy undergraduate students is $2.16(S D=0.71)$, which is at the level of low Computer internet Literacy. 
INTERNATIONAL JOURNAL OF ACADEMIC RESEARCH IN BUSINESS AND SOCIAL SCIENCES Vol. 10, No. 5, May, 2020, E-ISSN: 2222-6990 @ 2020 HRMARS

Table 4: The level of Computer Internet Literacy toward Perceive Usefulness of Online Learning $(n=631)$

\begin{tabular}{lccc}
\hline Program / level & $\begin{array}{c}\text { MC110 } \\
(\mathrm{n}=358)\end{array}$ & $\begin{array}{c}\text { MC111 } \\
(\mathrm{n}=155)\end{array}$ & $\begin{array}{c}\text { MC242 } \\
(\mathrm{n}=118)\end{array}$ \\
\hline Low & $\%$ & $\%$ & 8.5 \\
Moderate & 23.7 & 14.2 & 43.2 \\
High & 47.2 & 47.1 & 48.3 \\
Mean & 29.1 & 38.7 & 2.40 \\
\hline MC110 = Diploma in Communication and Media, MC111 = Diploma in New Media and \\
Contentpreneurship, MC242 = Bach. of Mass Comm. (Hons) Public Relations \\
Mean=2.16; SD=0.71 & 2.05 & 2.25 \\
\hline
\end{tabular}

From the Table 5, the level of students' Self-Dependent Learning in Perceive Usefulness of Online Learning is low (Mean = 1.89) with a range mean by program from 1.81 (MC110) to 2.07 (MC242). When examined in terms of the percentage of distribution at high level, MC242 program is the higher (27\%) follow by MC111 (18.7\%) and MC110 (12.8\%).

Table 5 : The level of Self-Dependent Learning toward Perceive Usefulness of Online Learning $\underline{(n=631)}$

\begin{tabular}{lccc}
\hline Program / level & $\begin{array}{c}\text { MC110 } \\
(n=358)\end{array}$ & $\begin{array}{c}\text { MC111 } \\
(n=155)\end{array}$ & $\begin{array}{c}\text { MC242 } \\
(n=118)\end{array}$ \\
\hline Low & $\%$ & $\%$ & 20.4 \\
Moderate & 31.8 & 25.8 & 52.5 \\
High & 55.3 & 55.5 & 27.1 \\
Mean & 12.8 & 18.7 & 2.07 \\
\hline
\end{tabular}

MC110 = Diploma in Communication and Media, MC111 = Diploma in New Media and Contentpreneurship, MC242 = Bach. of Mass Comm. (Hons) Public Relations

Mean=1.89; $S D=0.66$

From the Table 6, this study found that the level of motivation of learning among program is also at low level (1.77) with a range mean by program from 1.75 (MC111) to 1.95 (MC242). It mean that all respondent did not have motivation of learning during Covid-19. In addition those with high level of motivation of learning show that all programs have a low percentage of $13.5 \%$ (MC111) to $22.1 \%$ (MC242). 
INTERNATIONAL JOURNAL OF ACADEMIC RESEARCH IN BUSINESS AND SOCIAL SCIENCES Vol. 10, No. 5, May, 2020, E-ISSN: 2222-6990 @ 2020 HRMARS

Table 6 : The level of Motivation of Learning toward Perceive Usefulness of Online Learning $(n=631)$

\begin{tabular}{lccc}
\hline Program / level & $\begin{array}{c}\text { MC110 } \\
(\mathrm{n}=358)\end{array}$ & $\begin{array}{c}\text { MC111 } \\
(\mathrm{n}=155)\end{array}$ & $\begin{array}{c}\text { MC242 } \\
(\mathrm{n}=118)\end{array}$ \\
\hline Low & $\%$ & $\%$ & 27.1 \\
Moderate & 41.9 & 38.1 & 50.8 \\
High & 43.8 & 48.4 & 22.1 \\
Mean & 14.2 & 13.5 & 1.95 \\
\hline
\end{tabular}

MC110 = Diploma in Communication and Media, MC111 = Diploma in New Media and Contentpreneurship, MC242 = Bach. of Mass Comm. (Hons) Public Relations

Mean=1.77; SD=0.69

\section{Discussion}

This study conducted to measure Faculty of Communication and Media Studies (FKPM) undergraduate students' online distance learning readiness and the survey conducted pre-online distance learning (ODL_ session purposely to get some view for lesson planning by the lecturers. In order to measure students' online learning readiness, the researchers outline possible factors from previous study such as computer/internet literacy, self-dependent learning and motivation of learning (Hung et al., 2010). From the data, we found that FKPM undergraduate students are possess high computer/Internet Literacy (CIL). Not surprisingly, the students are able to use computer, searching materials through Internet and use any applications or software for ODL such as Google Classroom, Google Meet, Zoom meeting and uFuture (university system develop for online learning platform).

This association may relate to nature of the program which demand students must have computer in order to complete course assessment tasks and facilities available in campus along the study (Li \& Lee, 2016). From Table 4 this study reported that MC242 (bachelor program) possess high CIL skills than other diploma program (MC111 and MC110) and this is due to maturity of the students and educational background (Navani \& Ansari, 2017) that expose them be able to work with software and hardware even during ODL. Even though many study claimed that ODL was exposed students with technology anxiety, especially computer anxiety and this study revealed that by having greater experience working with computer can increase self-efficacy (Keis et al., 2017), enhance CIL skills and directly reduced computer anxiety among students especially during ODL (Tuncay, 2010; Darwish, Ahmed, \& Pahi, 2020). The MC111 retain among the higher CIL skills than MC110 because nature of the study plan (Diploma in New Media and Contentpreneurship) exposed the students working greater level with technology such as applications, software and hardware than MC110 (Diploma in Communication and Media).

Another factors affect student online distance learning readiness level is self-directed learning (SDL). The essence of SDL to measure student online distance learning readiness is to test level of internal monitoring, external monitoring and motivational monitoring among undergraduate students. Students are expected to have high motivation of learning to forecast personal performance and plan personal responsibility by managing cognitive performance to achieve learning outcomes (D R Garrison, 1997). As undergraduate students in Public University, they are expecting to 
INTERNATIONAL JOURNAL OF ACADEMIC RESEARCH IN BUSINESS AND SOCIAL SCIENCES Vol. 10, No. 5, May, 2020, E-ISSN: 2222-6990 @ 2020 HRMARS

have greater SDL due to previous academic achievement. High SDL level students must be able to carry out their own study plan, managing time very well and having high expectation for learning performance (Yu \& Richardson, 2015). Therefore, this study take into account SDL level among undergraduate students in FKPM in order to analyse students online distance learning readiness (Hung et al., 2010). Surprisingly, learners who have high academic performance from previous achievement and this study found all three programs reported low level of SDL. This findings reported that students are not be able to manage the internal monitoring (cognitive factors), external monitoring (environment factors) and motivational monitoring among undergraduate students. Study by Adams et al., (2018) who study on e-learning readiness among students in Higher Education Institution propose that to get high level of SDL and greater readiness, students must have high technology usage, better technology availability and facility.

As discuss in Table 4, respondent do not face any constraint of using the technology for ODL and reported $\mathrm{CIL}$ in high level for the three programs. What factors seems affect SDL level? Low level of SDL justified with number of factors; 1) nature mode of study (Park \& Yun, 2017), 2) low face-toface social interaction with support group (El-Seoud, 2016) and 3) low self-directed learning to perform course assessment task (Yilmaz, 2017). All undergraduate program in FKPM running in UiTM Melaka offered in full time based and naturally, course content delivered $10 \%$ blended learning and 90\% face-to-face with direct interaction with the lecturer. While, ODL mode totally strange to undergraduate students who never facing $100 \%$ online learning with minimum interaction to the lecturer. This factor may lead to low level of SDL even high level for CIL. In addition, ODL mode allow the lecturer and students interaction through virtual platform and very minimum contact because of Internet connection and most of the lecturer manage to have Google meet session in less than 1 hour as suggested by the university management due to Internet access among student.

Besides CIL and SDL, another factors that affect student online distance learning level is motivation of learning (MOL). In order to measure level of $\mathrm{MOL}$, the researcher eager to know what motivate the students to join ODL activities and any potential destruction may affect their focus to maintain high motivated learner. Many online learning study reported that $\mathrm{MOL}$ is a crucial factor for the students to maintain focus to achieve high academic performance due to many issues such as family, environment and technical destruction, especially during MCO. Compared to online learning course as the nature, ODL learning during MCO affect emotional and mental stability.

Learning environment is not conducive due to all family members stay at home and limited space to do revision and perform course assessment task these are the factors predicted affect MOL level among undergraduate students. Besides, technical destruction such as computer failed to run smoothly, limited Internet data and single device being used by many family members to perform work task are the issues raised that affect MOL level. Another potential factor that affect MOL level is lack of interaction with the lecturer to perform course assessment task. Lack of understanding to do the assessment and the lecturer keep forcing for progress submission positively affect MOL level among undergraduate students. Online learning open new method of interactive learning and also expose the students with potential issues with low level of MOL that affect online learning readiness.

There many suggestion by previous researcher on how to increase or sustain readiness level and this study conclude all ideas as ARP. The ARP strategies refers to attention, recognition and pressure less. The attention through frequently interaction spent by lecturer toward students was expected to increase the readiness level. By having social interaction through virtual platform, the lecturer deliver briefing about course assessment frequently, QnA session from students being 
answered effectively and any motivational say for the students to sustain their focus and strike for excellence. As for recognition, any good behaviour such as full attendance of participation, best students' performance for the lesson or assessment (EI-Seoud, 2016) being rewarded. This initiative taken by the lecturer directly spark their interest to sustain student best achievement and performance. Next, strategy is pressure less. Do not put strict fix time for attendance, participation and submission for led to a higher level of involvement to the courses and a willingness to actually join the ODL session until the end.

\section{Conclusion}

Surprisingly, findings reported from this study was evolved teaching and learning activities made to ensure student online distance learning readiness at premium level. This study found that CIL among undergraduate students are at high level, while SDL and MOL reported at low level. This study suggest the ARP initiative taken by the lecturer. The A.R.P refers to attention, recognition and pressure less. The objective of ODL is not only to complete the semester but to strike the excellence academic performance and finally, contribute towards university academic quality. The ODL seems new norms that should not hinder potential interactive learning for best academic performance to drive excellent achievement. Future researcher may examine the effectiveness of ARP initiative to enhance student's self-directed learning and motivation for ODL. It is important to have learner analytic data for the lecturer and management setup best ODL implementation. Besides, the study contributes to the present body of knowledge on ODL practice and student readiness. The main contribution of this article also provides directions for the lecturer, faculty management and to the university to apply best practice of ODL in future. Suggestion for future study to explore the effectiveness of ARP initiative for ODL implementation effectiveness towards undergraduate students. This is valuable finding that contribute towards students, lecturers, faculty management, university and HEI.

\section{References}

Adams, D., Sumintono, B., \& Mohamed, A. (2018). E-Learning Readiness Among Students Of Diverse Backgrounds In A Leading Malaysian Higher Education Institution. Malaysian Journal Of Learning And Instruction, 15(2), 227-256.

Ajmal, M., \& Ahmad, S. (2019). Exploration Of Anxiety Factors Among Students Of Distance Learning : A Case Study Of Allama Iqbal Open University. Bulletin Of Education And Research, 41(2), 67-78.

Alem, F., Plaisent, M., Zuccaro, C., \& Bernard, P. (2016). Measuring E-Learning Readiness Concept: Scale Development And Validation Using Structural Equation Modeling. International Journal Of E-Education, E-Business, E-Management And E-Learning, 6(4), 193-207.

Annuar, N., \& Shaari, R. (2014). Transformation Of Self-Directed Learning Abilities Among Distance Learner. Journal Of Social Science Research, 4(1), 415-421.

Barak, M., Hussein-Farraj, R., \& Dori, Y. J. (2016). On-Campus Or Online : Examining Self- Regulation And Cognitive Transfer Skills In Different Learning Settings. International Journal Of Educational Technology In Higher Education.

Bhat, S., Raju, R., Bikramjit, A., \& Souza, R. D. (2018). Leveraging E-Learning Through Google Classroom : A Usability Study. Journal Ofengineering Education Transformations, 31(3), 129135.

Casaló, L. V., Flavián, C., \& Guinalíu, M. (2010). Determinants Of The Intention To Participate In FirmHosted Online Travel Communities And Effects On Consumer Behavioral Intentions. Tourism 
INTERNATIONAL JOURNAL OF ACADEMIC RESEARCH IN BUSINESS AND SOCIAL SCIENCES

Vol. 10, No. 5, May, 2020, E-ISSN: 2222-6990 @ 2020 HRMARS

Management, 31(6), 898-911.

Chen, A. E. W. \& J. V. (2017). Online Learners' Motivation In Online Learning : The Effect Of OnlineOnline Learners' Motivation In Online Learning: The Effect Of Online - Participation, Social Presence, And Collaboration. E-Learning Journal, 23, 72-93.

Cooper, M. (2006). Making Online Learning Accessible To Disabled Students : An Institutional Case Study. Research In Learning Technology, 14(1), 103-115.

Darwish, S., Ahmed, U., \& Pahi, M. H. (2020). Innovative Work Behavior During COVID-19 for Medical Representative in the Pharmaceutical Industry: Test of a Moderation Model in Bahrain. International Journal of Pharmaceutical Research. 12(4), 19271934. doi.org/10.31838/ijpr/2020.12.04.277Deschacht, N., \& Goeman, K. (2015). The Effect Of Blended Learning On Course Persistence And Performance Of Adult Learners: A Difference-InDifferences Analysis. Computers \& Education, 87, 1-18.

Doculan, J. A. D. (2016). E-L Earning R Eadiness A Ssessment T Ool F Or P Hilippine H Igher E Ducation I Nstitutions. International Journal On Integrating Technology In Education, 5(2), 33-43.

Foon, K., \& Sum, W. (2014). Students ' And Instructors' Use Of Massive Open Online Courses ( Moocs ): Motivations And Challenges. Educational Research Review, 12(June), 45-58.

Garrison, D. R. (1987). Self - Directed And Distance Learning : Facilitating Self - Directed Learning Beyond The Institutional Setting. International Journal Of Lifelong Education, 6(4), 309-318.

Garrison, D. R. (1997). Self-Directed Learning: Toward A Comprehensive Model. Adult Education Quarterly, 48(1), 18-33.

Hair, J. F., Black, W. C., Babin, B. J., \& Anderson, R. E. (2014). Multivariate Data Analysis. Pearson Education Limited.

Hernández-Sellés, N., \& Muñoz-Carril, P. (2019). Computers \& Education Computer-Supported Collaborative Learning: An Analysis Of The Relationship Between Interaction, Emotional Support And Online Collaborative Tools. Computers \& Education, 138(February), 1-12.

Hung, M., Chou, C., Chen, C., \& Own, Z. (2010). Computers \& Education Learner Readiness For Online Learning : Scale Development And Student Perceptions. Computers \& Education, 55(3), 10801090.

Hussin, S., Manap, M. R., Amir, Z., \& Krish, P. (2017). Mobile Learning Readiness Among Malaysian Students At Higher Learning Institutes. Asian Social Science, 8(12), 276-283.

Keis, O., Grab, C., Schneider, A., \& Öchsner, W. (2017). Online Or Face-To-Face Instruction ? A Qualitative Study On The Electrocardiogram Course At The University Of Ulm To Examine Why Students Choose A Particular Format. Medical Education Online, 17, 1-8.

Kenny, Z. Z., \& R. F. (2010). Learning In An Online Distance Education Course : Experiences Of Three International Students. International Review Of Research In Open And Distance Learning, 11(1), 18-36.

Kuo, Y., Walker, A. E., Schroder, K. E. E., \& Belland, B. R. (2014). Internet And Higher Education Interaction, Internet Self-Ef Fi Cacy, And Self-Regulated Learning As Predictors Of Student Satisfaction In Online Education Courses. The Internet And Higher Education, 20(1), 35-50.

Li, L., \& Lee, L. (2016). Computer Literacy And Online Learning Attitude Toward Gsoe Students In Distance Education Programs. Higher Education Studies, 6(3), 147-156.

Navani, Y., \& Ansari, M. A. (2017). Assessing E-Learning Readiness Of University Faculty In India. Advances In Computer Science And Information Technology, 4(3), 209-214.

Park, S., \& Yun, H. (2017). Relationships Between Motivational Strategies And Cognitive Learning In 
INTERNATIONAL JOURNAL OF ACADEMIC RESEARCH IN BUSINESS AND SOCIAL SCIENCES

Vol. 10, No. 5, May, 2020, E-ISSN: 2222-6990 @ 2020 HRMARS

Distance Education Courses. Distance Education, 7919(September), 1-19.

Saadé, R. G., Kira, D., Mak, T., \& Nebebe, F. (2017). Anxiety And Performance In Online Learning. Proceedings Of The Informing Science And Information Technology Education Conference, 147157.

Samir, A. El-S. (2016). Motivation In E-Learning: How Do We Keep Learners Motivated In An ELearning Environment? E-Learning And Digital Media, 12(2), 1-5.

Suprabha, B. S., Shenoy, R., Rao, A., Rao, A., \& Naik, D. G. (2017). Readiness And Utilization Of Computer-Assisted Learning Among Dental Students And Faculty. Dental Hypotheses, 8(4), 8793.

Thammathirat, S., \& Tuntirojanawong, S. (2013). Students ' Readiness For E-Learning : A Case Study Of. Journal Of Learning In Higher Education, 9(1), 59-66.

Tuncay, N. (2010). Anxiety And Resistancen In Distance Learning. Cypriot Journal Of Educational Sciences, 5, 142-150.

Wallace, R. M. (2010). Online Learning In Higher Education : A Review Of Research On Interactions Among Teachers And Students Online Learning In Higher Education: A. Education, Communication \& Information, 3(2), 37-41.

Yang, J. C., Lin, M. Y. D., \& Chen, S. Y. (2018). Effects Of Anxiety Levels On Learning Performance And Gaming Performance In Digital Game - Based Learning. Journal Of Computer Assisted Learning, 1(May 2017), 1-11.

Yilmaz, R. (2017). Computers In Human Behavior Exploring The Role Of E-Learning Readiness On Student Satisfaction And Motivation In Fl Ipped Classroom. Computers In Human Behavior, 70(1), 251-260.

Yu, T., \& Richardson, J. C. (2015). An Exploratory Factor Analysis And Reliability Analysis Of The Student Online Learning Readiness ( Solr ) Instrument. Online Learning Journal, 19(5), 120-141.

Zainuddin, Z. (2019). How Do Students Become Self-Directed Learners In The Efl Flipped-Class Pedagogy ? A Study In Higher Education. Indonesian Journal Of Applied Linguistics, 8(3), 278690.

Zhu, M., Bonk, C., \& Sari, A. R. (2018). Instructor Experiences Designing Moocs In Higher Education : Pedagogical , Resource, And Logistical Considerations And Challenges. Online Learning Journal $-, 22(4), 204-241$. 